Article

\title{
Sustainable Relationship Development between Hotel Company and Its Employees: Linking Job Embeddedness, Job Satisfaction, Self-Efficacy, Job Performance, Work Engagement, and Turnover
}

\author{
Jongsik Yu ${ }^{1}$, Antonio Ariza-Montes ${ }^{2}$ (D) Gabriele Giorgi ${ }^{3}$, Aejoo Lee ${ }^{4}$ and Heesup Han ${ }^{4, *}$ \\ 1 Division of Tourism and Hotel Management, Cheongju University, 298 Daesung-ro, Cheongwon-gu, \\ Cheongju-si, Chungcheongbuk-do 28503, Korea; andyjs.yu@gmail.com \\ 2 Department of Management, Universidad Loyola Andalucía, C/ Escritor Castilla Aguayo, \\ 4, 14004 Córdoba, Spain; ariza@uloyola.es \\ 3 Department of Human Science, Università Europea di Roma, Via degli Aldobrandeschi, \\ 190, 00163 Roma, Italy; gabriele.giorgi@unier.it \\ 4 College of Hospitality and Tourism Management, Sejong University, 98 Gunja-Dong, Gwanjin-Gu, \\ Seoul 143747, Korea; leeaj@sejong.ac.kr \\ * Correspondence: heesup@sejong.ac.kr
}

Received: 27 July 2020; Accepted: 28 August 2020; Published: 2 September 2020

\begin{abstract}
This study aimed to investigate the impact of hotel employees' perceived job embeddedness on job satisfaction, self-efficacy, turnover intention, job performance, and job commitment. The results showed that job embeddedness partially increased job satisfaction, while job satisfaction and self-efficacy reduced turnover intention and increased job performance and job commitment. Furthermore, job satisfaction and self-efficacy were found to play an important mediating role. Therefore, the theoretical framework, based on the results of this study, clearly demonstrated the causal relationship between the given variables, and adequately describes the goals of this study. The theoretical/practical implications are discussed in detail in the conclusion.
\end{abstract}

Keywords: sustainable relationship development; organizational psychology; job embeddedness; job satisfaction; self-efficacy; turnover intention; perceived job performance; work engagement

\section{Introduction}

After the Asian financial crisis, the information technology bubble decay and financial crises arising from the U.S. such as the subprime mortgage crisis, the paradigm of jobs for life and job stability has largely crumbled in Korean enterprises [1]. Such changes led to unstable types of employment (e.g., temporary, outsourced, seasonal contract and short-term contracts) as well as a new culture of turnover (e.g., voluntary turnover for career advancement, involuntary turnover through restructuring) in the hospitality industries. This is an employment characteristic of the hospitality industry in South Korea at present. At the center of such change, there were employees who are regarded as the new generation. Individuals of the new generation showed slight differences in individual life priorities when compared to the older generation. The older generation placed utmost importance on jobs and work, directly related to survival; moreover, they had a strong inclination towards production, resulting in a very limited range of needs that mostly relate to survival and stable lifestyles. On the other hand, the new generation had a diverse range of interests, were influenced by more affordable economic environments, the globalization experience and the development of popular consumption culture, and tended to have an individualistic set of values that place importance on what they want to 
do. Since 2008, the proportion of new-generation employees in the Korean labor force reached $20 \%$ and continued to increase [2]. With the increase of new generation employees in a corporation, there were a range of side effects; a leading side effect was increasing turnover. Therefore, firms strived to establish strategies to access and maintain human capital to resolve the issue of turnovers [3].

According to Lee et al. [4], the costs that must be absorbed, such as those for training, the search for a replacement, and opportunity loss by a firm when an employee changes jobs, are equivalent to the employee's annual salary. Therefore, studies on employee turnover have been conducted according to the fluctuations in the turnover level, which exerts various negative effects such as an increase in firms' expenses. Early research on turnovers largely focused on exploring the factors that influence turnover [5]. Many studies focused on attitude factors such as job satisfaction and work engagement [6]. However, they were insufficient in explaining the reason why the employees were leaving. As such, studies began to take interest in the reason why employees would stay, rather than to leave, resulting in a new concept relating to turnover, job embeddedness (fit, links, sacrifice). As a result, many studies provided a diverse range of considerations on human capital management along with the importance of job embeddedness [7-12].

At the present time, when the number of new-generation employees continues to increase as a proportion of members of organizations, and especially given the fact that service-oriented firms such as hotel enterprises are largely composed of new-generation employees, it appears necessary to research the correlations between job embeddedness, job satisfaction, self-efficacy, turnover intention, job performance and work engagement, based on the concept of employees' remaining in the firm. Given these, this study seeks answers for the following 3 research questions:

1. How does job embeddedness perceived by employees of hotel enterprises influence turnover intention, job performance and work engagement through job satisfaction and self-efficacy?

2. If such influences exist, which constituents of job embeddedness are the most influential?

3. For the strongly individualistic new-generation employees, do job satisfaction and self-efficacy work to reduce turnover intention and increase job performance and work engagement?

Following the introduction, this study briefly covers the concepts of constituents of job embeddedness, job satisfaction, self-efficacy, turnover intention, job performance and work engagement. This is followed by an introduction to the study methodology, including the measurements of variables and sample characteristics. Lastly, considerations, limitations and directions of future studies are discussed based on the statistical results.

\section{Literature Review}

\subsection{Turnover of Hotel Employees}

Born around the 1980s, the new generation has matured in an environment of heightened economic well-being owing to rapid economic growth, an era of internationalization and development of information technology; they place importance on individual privacy rather than the well-being of the organization, and place heavy emphasis on work-life balance [2]. This characteristic of valuing individual privacy found in the new generation manifests itself in increasing turnover rates. The Kukmin Daily [13] reported that $42 \%$ of the new-generation, college-graduate new employees are preparing to move jobs, with $24 \%$ already going through the move and $18 \%$ preparing for the move. Moreover, $56 \%$ of the employees responded that they intended to move jobs in the future, with only $2 \%$ responding that their current place of work would be their work for the rest of their lives [13]. In Japan, troubled with sourcing human capital, Yonhap News Agency [14] reported that $30 \%$ of the college-graduate new hires had quit their jobs within the first 3 years; in terms of job sectors, hospitality and food service sectors led the group, at $50.5 \%$ of the total.

As the hotel industry is labor-intensive and highly dependent on human resources, human resource management is an essential function. In addition, effective business performance is best 
achieved when both facilities and services are managed simultaneously. Ramli et al. [15] argued that employee turnover may have a negative impact not only on the organization, but also on the remaining employees in the form of costs of hiring and training new employees, lack of motivation, and decreased productivity. In other words, employee turnover may cause both financial and non-financial losses for the organization and may even become a broader social problem. Therefore, the hotel industry must acknowledge the severity of employee turnover and make efforts to minimize it to adequately manage human resources and services, especially during periods when turnover rates in the industry are high.

\subsection{Job Embeddedness}

Job embeddedness is a concept demonstrating the individual level of embeddedness within the firm or their jobs, and refers to the comprehensive influence that induces individuals to stay within the organization [12]. Job embeddedness refers to continuous retention without leaving the organization, and thus may closely link the employees with the organization and their duties. In the literature, job embeddedness is characterized as a web. In other words, employees are connected in networks to related organizations, other employees, groups and situations, and such connections may limit turnover [8,12].

Mitchell et al. [12] classified the sub factors of job embeddedness as fit, links, and sacrifice, based on the concept of "Why remain?" instead of "Why change jobs?" First, fit refers to an employee's perceived compatibility with the organization and surrounding environment. Fit appears when an employee's personal values, goals and future plans match the firm's culture and the job, and this increases the possibility that the employee remains in the organization [16]. Moreover, one may feel satisfied and committed to the job, and may exert a positive impact on organizational development. Overall, fit is likely to develop into organizational attachment [12]. Second, links refer to the formal or informal connections between the organization and the individual [12]. Links become more important when an employee is connected more to the organization, the others, and the job [8], and employees with a greater number and intensity of connections are less likely to make a turnover decision that may break or rearrange the connections [16]. Third, sacrifice is defined as an opportunity cost of material or psychological benefits that may be forfeited by leaving the organization [12]. Opportunity cost in sacrifice includes clear costs that the employee must bear when changing jobs, such as loss of wages, promotion opportunities, relationships with colleagues, and job-related reputation. The construct of job embeddedness not only predicts turnover and turnover intention, but also explains the key change beyond job satisfaction. Therefore, by developing the concept of job embeddedness and using it as an active concept to increase organizational performance instead of merely using it as a passive concept to encourage employees to remain with the firm, job embeddedness may be a highly effective and useful tool for firms.

\subsection{Job Satisfaction}

Job satisfaction refers to the happy and positive state of emotions regarding their place of work and their jobs perceived by members of the organization [17], constitutes cognitive, emotional response towards their jobs and manifests itself through the comparison of actual results and expected results [18]. As the experience and satisfaction obtained through their job tend to transfer to the satisfaction levels towards life perceived by the individual, it influences the individually perceived level of satisfaction towards life and the growth of the firm [19]. The positive/negative emotions perceived by the members of the organization can manifest itself in individual tendencies, emotions, job characteristics and work environments [20]; when needs such as salary, promotion opportunities, welfare and benefits, work conditions, relationships with co-workers and organizational policies are sufficiently met, they may lead to positive attitude towards work such as engagement, excitement and interest towards the work they perform [21].

Karatepe and Uludag [22] utilized overall satisfaction towards work, satisfaction towards one's superiors and colleagues, organizational policies, support, salary, achievement opportunities and 
customer relationships as variables to measure job satisfaction; Messersmith et al. [23] utilized the variables of task satisfaction, employer satisfaction and overall satisfaction towards the job. Therefore, this study measured the wages, achievement opportunities, pleasure, and overall job satisfaction to measure the job satisfaction levels of hotel employees based on the studies of Hartline and Ferrell [24] and Kim et al. [25]. However, existing studies explore the role of variables to identify the relationships between standard leading variables and job satisfaction; there is a limited number of studies on the influence on job embeddedness, job satisfaction and turnover intention, all of which are important factors determining voluntary turnover. Specifically, there is even less research that simultaneously explores the positive and negative factors of hotels and job embeddedness with hotel enterprises.

\subsection{Self-Efficacy}

Self-efficacy is the belief or conviction of ability that can effectively execute actions to achieve tasks [26], and constitutes a self-evaluation on the overall ability to execute the required actions when faced with a specific situation [27]. This concept of self-efficacy displays the individual conviction of ability required to obtain results desired by the organization, and can be an important variable to understand the attitude and actions of an individual [28,29]. Job competency, self-confidence, and expertise, which can maximize one's job performance, were used in previous studies in order to measure self-efficacy [30,31].

According to social cognitive theory, there are 3 types of self-efficacy (i.e., magnitude, or the level or size of the job, strength, or the certainty that one can carry out a job at a difficult level, and generality, or standardization of all jobs or situations) [29]. Moreover, according to Pygmalion leadership, self-efficacy is explained based on the following 4 constituents of (1) enactive mastery experience: the direct influence of self-confidence in forming self-efficacy [26,32], (2) vicarious experience: observing the job processes of skilled employees, others can build self-confidence, obtain future-oriented information and enhance their own skills [33], (3) verbal persuasion: the positive encouragement and persuasion of a leader based on knowledge and trust can maximize self-efficacy [29,34], and, (4) psychological and affective states: evaluating one's own skills and continuous efforts can change actions and attitudes [26,35].

As the main idea behind the social cognitive theory, self-efficacy is not formed devoid of one's own efforts; it may be formed through learning, experiencing and vicarious effects within the organization, and tends to be strongly influenced by the presence/lack of experience of a certain issue or the resulting performance. According to empirical studies on the relationship between self-efficacy and various performances, they have continuously proven that self-efficacy is a strong predictor of individual performance [32,36-38]; these individual performances can be very closely related to corporate performance. Hence, firms need to train employees with high degrees of self-efficacy who are able to effectively carry out their job duties and are not easily influenced by internal or external environments.

\subsection{Turnover Intention}

Turnover intention represents a stage prior to the actual action of turnover, and refers to a psychological state where the member of the organization wishes to forfeit their role and leave the organization [39]. Turnover can be divided into voluntary turnover (i.e., due to causes such as salary, welfare, work environment, immigration, marriage or illness) and involuntary turnover where the employee leaves the organization resulting from corporate decisions (i.e., layoffs, dismissals, regular retirements and forced retirements). In organizational management, turnovers can result in financial losses such as job advertisements, marketing for new hires, educating and directing the new hires) [40], and may also lead to lower morale and hinder organizational engagement for members remaining within the organization. In particular, turnover occurring in the labor-intensive hotel industries can be regarded as being even more destructive. For such reasons, minimizing turnovers have been of critical importance for researchers and practitioners. Existing literature has claimed that turnover intention is the most important variable predicting turnover, by conducting meta-analysis [6,41,42]. Furthermore, many previous studies have used measurement items such as turnover intention, turnover plan, 
and turnover preparation to assess the turnover intentions of employees [43]. In other words, turnover intention is the leading variable and strong predictor of actual turnovers; as such, it is a variable that successfully explains employee turnover.

\subsection{Perceived Job Performance}

Job performance refers to the level of attainment of work of employees, and often depicts the achievement of organizational goals [44]. Job performance can be evaluated using criteria such as job competency, efficiency, ability and speed in handling tasks, accuracy, and goal attainment. Therefore, this study used and measured the degree of understanding, degree of skill acquisition, and degree of development of job skill and competency to measure job performance. However, there may be a gap between the appraiser and the appraised in terms of the criteria used to evaluate job performance. Since performance is a comprehensive concept that contains various meanings, there are limitations to clearly defining performance in a service industry like the hotel business. However, the concept of performance is a wide-reaching, construct concept that generally refers to positive effects, and is regarded from a positive perspective of attaining organizational objectives, despite some theoretical ambiguities [45].

Service companies like hotels have a distinct character in which interactions between employees and customers are face to face. In other words, there may be a gap in how job performance is evaluated between more general business enterprises and service companies like hotels. That is, while general business enterprises evaluate job performance from a financial perspective such as productivity or profitability, hotels evaluate it from a non-financial perspective such as customer feedback (e.g., letters of thanks, praise). This implies that there is a clear difference between the methods of evaluating job performance for ordinary companies and for service companies such as hotels.

\subsection{Work Engagement}

Work engagement refers to accepting the goals and values of the organization, and the attitude of doing the utmost for the organization. It can be defined in terms of positivity, fulfilling, passion related to the job, and dedication [46]. Vigor refers to high levels of energy and mental resilience while working, and the willingness to invest effort in one's work. Dedication refers to experiencing a sense of significance, enthusiasm, inspiration, pride, and challenge in attainment of the organization's goals [46]. Employees with a higher work engagement more accurately perceive their work and participate more actively and enthusiastically in their jobs. Moreover, looking beyond current tasks, they set challenging goals, have an adventurous spirit, and advance toward the fulfillment of goals. Work engagement performs a significant role in increasing employee enthusiasm and providing quality work atmosphere. Those with attachment to and enthusiasm for their jobs can contribute to organizational performance. Moreover, work engagement has become a measure of an organization's investment in human capital [47]. Therefore, the importance of work engagement is constantly increasing

\subsection{Relationships among Study Variables}

Work embeddedness is an important factor that explains why employees remain within an organization, and provide important considerations on the employees' affinity towards the organization. Due to such reasons, job embeddedness has been defined as a concept focusing on the choices of employees to remain, and numerous studies have proven correlations with turnover and turnover intention since related indicators have been presented $[7,11,48]$. Moreover, variables that have been most frequently studied as predictors of turnover intention are job satisfaction and organizational engagement, with many studies presenting the positive influence of job embeddedness on job satisfaction [5,12,49]. Specifically, Jiang et al. [49] showed that the correlation between job satisfaction and cognitive engagement was the most significant through meta-analysis. Given these, this study has set the following hypotheses: 
Hypothesis 1 (H1). Fit has a positive influence on job satisfaction.

Hypothesis 2 (H2). Links have a positive influence on job satisfaction.

Hypothesis 3 (H3). Sacrifice has a positive influence on job satisfaction.

Many researchers have studied the influence of job satisfaction on self-efficacy, turnover intention, job performance and job engagement. Judge and Bono [50] performed a meta-analysis on the correlations between 4 variables (i.e., job satisfaction, self-worth, self-efficacy and emotional stability), and concluded that self-efficacy showed the highest correlation with job satisfaction. Jang and George [51] and Moshin et al. [52] researched the influence of job satisfaction on turnover intention with hotel employees $(609,884$ employees, respectively). The results indicated that higher job satisfaction led to lower turnover intention. Arnett et al. [53], in their study on the influence of job satisfaction on positive employee behavior, concluded that employees satisfied with their jobs led to an overall rise in job performance, such as better customer service, better relationships with colleagues and improved organizational engagement. Furthermore, Chen and Wang [54] asserted that turnover intention decreases when the job satisfaction of hotel employees improves. Lu and Gursoy [55] explained that job satisfaction is a factor that can reduce turnover intention, which has a negative effect on the performance of an organization. Thus, it can be asserted that job satisfaction prevents the departure of employees, and is highly relevant in improving organizational profitability and productivity through job performance and engagement. Based on these, the present study has set the following hypotheses:

Hypothesis 4 (H4). Job satisfaction has a positive influence on self-efficacy.

Hypothesis 5 (H5). Job satisfaction has a negative influence on turnover intention.

Hypothesis 6 (H6). Job satisfaction has a positive influence on job performance.

Hypothesis 7 (H7). Job satisfaction has a positive influence on work engagement.

Self-efficacy can be defined as the belief in one's capacity required to attain the goals assigned to an individual [26]. Many existing studies have concluded that self-efficacy is a determining variable of behavioral changes, and an important predictor of various forms of job performance [38]. Specifically, according to studies by Steers [56] and Mathieu, [57], self-efficacy refers to positive energy to attain one's goals and facilitates job satisfaction and work engagement, ultimately resulting in higher job performance and lower turnover intention. These results indicate that higher self-efficacy in employees lead to higher satisfaction towards their job, affinity towards the organization and work engagement, ultimately having a positive influence on organizational productivity $[50,58]$. Accordingly, this study has set the following hypotheses:

Hypothesis 8 (H8). Self-efficacy has a negative influence on turnover intention.

Hypothesis 9 (H9). Self-efficacy has a positive influence on job performance.

Hypothesis 10 (H10). Self-efficacy has a positive influence on work engagement.

\subsection{Proposed Model}

Based on the evidence presented by the existing literature, this study has proposed 10 hypotheses that pertain to its purpose. The 10 hypotheses and proposed study model is shown in Figure 1. 


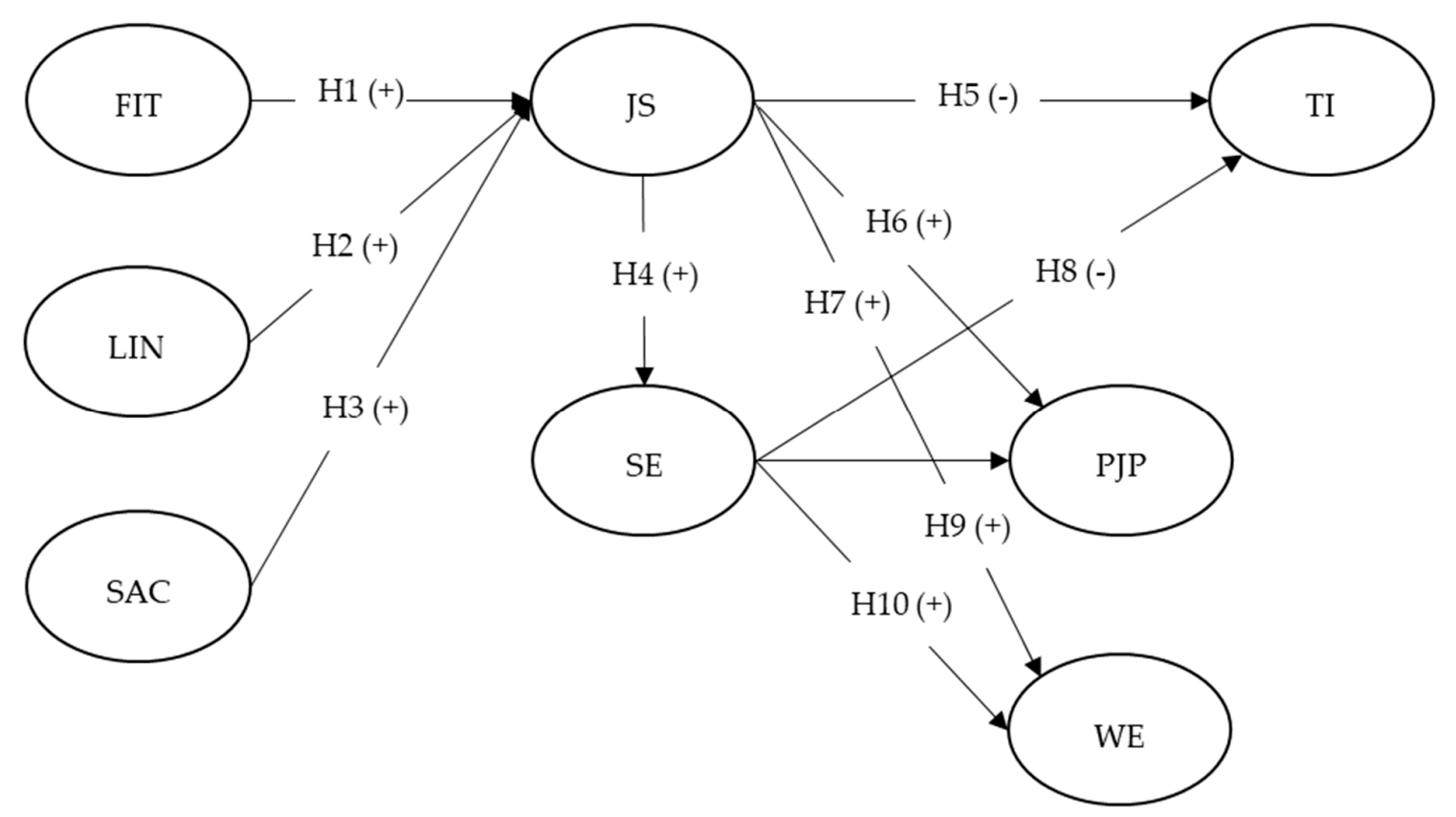

Note. FIT = fit, LIN = links, SAC = sacrifice, $J S=$ job satisfaction, $S E=$ self-efficacy, $\mathrm{TI}=$ turnover intention, $\mathrm{PJP}=$ perceived job performance, $\mathrm{WE}=$ work engagement

Figure 1. The proposed model.

\section{Methods}

\subsection{Measurement and Questionnaire Development}

The survey questions of this study were largely divided into 3 types (details on the study, questions regarding variables and demographic information). All measurement items had proven validity in previous literature, and were items that were common in studies regarding job embeddedness and turnover intention. In addition, the commonly used 5-point Likert and multi-item scales were utilized when measuring the variables in this research. Specifically, among the 10 job embeddedness questions with proven validity from existing studies, 4 items pertained to fit, 3 items pertained to links and 3 items pertained to sacrifice; 4 items were utilized each for the variables of job satisfaction, self-efficacy, perceived job performance and work engagement; 3 items were utilized for turnover intention. The first version of the survey utilized in this study was subject to a pretest with 3 groups (e.g., 1. College professor whose expertise is human resource management in hotel enterprises, 2 . Manager-level employee working at a luxury hotel, 3. Graduate students majoring in hotel management). Pretests were conducted with these 3 groups, and survey items were modified based on the results.

\subsection{Data Collection and Sample Profile}

A self-reported questionnaire survey was conducted to collect data for the empirical analysis (please see the Appendix A). The 115 -star hotels located in Seoul, the capital of South Korea, and the surrounding capital region were selected for the survey. A total of 450 questionnaires were distributed to employees of the room, food and beverage, sales and marketing, finance, and human resources (HR) divisions in the hotels. A total of 324 questionnaires (response rate $=72 \%$ ) were collected through these methods. 6 outliers deemed to be inappropriate for the empirical analysis of this study were excluded. Empirical analysis was conducted using the 318 samples that were ultimately collected for this research. A total of 44.7\% (142) of the respondents were male and 55.3\% (176) were female. The majority of the respondents $(87.2 \%, 277)$ were in their 20 s and 30 s, while the remainder $(12.9 \%, 41)$ were in their $40 \mathrm{~s}$ and $50 \mathrm{~s}$. A total of $73 \%$ (232) of the employees had less than 7 years' experience, while the remainder $(27 \%, 86)$ had over 7 years' experience; $33.6 \%$ of the respondents were in Rooms 
$(n=107), 37.4 \%$ in Food and Beverages $(n=119), 24.8 \%$ in Sales and Marketing $(n=79), 2.2 \%$ in Finance $(n=7), 0.9 \%$ in Human Resources $(n=3)$ and $0.9 \%$ in other departments $(n=3)$. The job titles of the respondents were as follows: Staff $64.8 \%(n=206)$, Supervisor $26.1 \%(n=83)$, Assistant Manager $6.3 \%(n=20)$, Manager 2.5\% $(n=8)$, Senior Manager $0.3 \%(n=1)$. When the salaries of the respondents were denoted in U.S. currency from Korean currency, the salary range with the highest proportion was $\$ 20,000-\$ 29,999(49.1 \%)$, followed by $\$ 30,000-\$ 39,999$ (19.2\%), below $\$ 20,000(17.3 \%), \$ 40,000-\$ 49,999$ $(8.5 \%)$ and more than $\$ 50,000(6 \%)$. The majority of the respondents were single $(72 \%)$, and $28 \%$ of the respondents were married. Lastly, in terms of educational attainment, 266 respondents had college degrees $(83.6 \%)$, with 52 respondents with graduate degrees $(16.4 \%)$.

\section{Results}

\subsection{Confirmatory Factor Analysis}

This study conducted an empirical analysis using SPSS 22 and Amos 22. Confirmatory factor analysis (CFA) was conducted using the maximum likelihood estimation method to test the unidimensionality of the scale and validity of the measurement model. CFA is an analytical method used most effectively to test the reliability and validity of the scale [59,60]. The analysis results are as follows. The goodness of fit of the model was statistically acceptable $\left(X^{2}=731.472(\mathrm{df}=244, p<0.001)\right.$, RMSEA $=0.79, \mathrm{CFI}=0.919$, IFI $=0.920$ ). There is convergent validity if AVE that tests convergent validity is higher than 0.5 and CR that tests internal consistency is higher than 0.7 [61]. The results of the empirical analysis showed that AVE ranged from 0.569 to 0.790 , and CR ranged from 0.757 to 0.917 . Therefore, the variables used in the empirical analysis were proven to have internal consistency and convergent validity. Moreover, all correlation coefficients in Table 1 were 0.8 or lower, and AVE was greater than the square of the correlation coefficient among latent variables, thereby showing that there was nothing wrong with discriminant validity as well [61].

Table 1. Correlation, mean, standard deviation (SD), average variance extracted, and reliability.

\begin{tabular}{ccccccccc}
\hline & FIT & LINK & SAC & JS & SE & TI & PJP & WE \\
\hline FIT & $0.890^{\mathrm{a}}$ & & & & & & & \\
\hline \multirow{2}{*}{ LINK } & $0.546^{\mathrm{b}}$ & 0.757 & & & & & & \\
& $(0.298)^{\mathrm{c}}$ & & & & & & \\
SAC & 0.562 & 0.519 & & & & & & \\
& $(0.315)$ & $(0.269)$ & 0.794 & & & & & \\
JS & 0.612 & 0.401 & 0.666 & 0.839 & & & & \\
& $(0.374)$ & $(0.160)$ & $(0.443)$ & & & & \\
SE & 0.196 & 0.375 & 0.154 & 0.206 & 0.868 & & & \\
& $(0.038)$ & $(0.140)$ & $(0.23)$ & $(0.042)$ & & & & \\
TI & -0.471 & -0.200 & -0.398 & -0.561 & 0.076 & 0.878 & & \\
& $(0.221)$ & $(0.040)$ & $(0.158)$ & $(0.314)$ & $(0.005)$ & & & \\
PJP & 0.346 & 0.425 & 0.277 & 0.281 & 0.541 & -0.082 & 0.917 & \\
& $(0.119)$ & $(0.180)$ & $(0.076)$ & $(0.078)$ & $(0.292)$ & $(0.006)$ & & \\
WE & 0.445 & 0.371 & 0.358 & 0.538 & 0.483 & -0.323 & 0.498 & \\
& $(0.198)$ & $(0.137)$ & $(0.128)$ & $(0.289)$ & $(0.233)$ & $(0.104)$ & $(0.248)$ & 0.856 \\
Mean & 3.400 & 3.372 & 2.937 & 2.729 & 3.614 & 3.154 & 3.588 & 3.391 \\
SD & 0.859 & 0.879 & 0.979 & 0.966 & 0.869 & 1.136 & 0.672 & 0.740 \\
AVE & 0.732 & 0.610 & 0.569 & 0.567 & 0.622 & 0.706 & 0.790 & 0.667 \\
\hline
\end{tabular}

Note 1. FIT $=$ fit, LIN $=$ links, SAC $=$ sacrifice, JS $=$ job satisfaction, $\mathrm{SE}=$ self-efficacy, $\mathrm{TI}=$ turnover intention, $\mathrm{PJP}=$ perceived job performance, $\mathrm{WE}=$ work engagement. Note 2. Goodness-of-fit statistics: $\chi^{2}=731.472, d f=244$, $p<0.001, \chi^{2} / d f=2.998$, RMSEA $=0.079, \mathrm{CFI}=0.919, \mathrm{IFI}=0.920, \mathrm{TLI}=0.903$. ${ }^{\mathrm{a}}$ Composite reliability, ${ }^{\mathrm{b}}$ Squared correlations, ${ }^{\mathrm{C}}$ Squared correlations. 


\subsection{Structural Model Results and Hypotheses Testing}

Maximum likelihood estimation was used to verify the fit of the proposed research model. The results indicated that model fit $\left(\chi^{2}=777.032, \mathrm{df}=258, p<0.001, \chi^{2} / \mathrm{df}=3.035, \mathrm{RMSEA}=0.080\right.$, $\mathrm{CFI}=0.914$, IFI $=0.914, \mathrm{TLI}=0.899)$ was satisfactory. In addition, the variables of turnover intention $\left(R^{2}=0.444\right)$, perceived job performance $\left(R^{2}=0.372\right)$, and job commitment $\left(R^{2}=0.471\right)$ were shown to have appropriate explanatory power within the theoretical framework. Therefore, it can be concluded that the model presented herein is very appropriate for predicting turnover intention. The detailed results are presented in Table 2 and Figure 2.

Table 2. Coefficient, $t$-value, total impact, indirect impact, $\mathrm{R}^{2}$, and hypotheses testing.

\begin{tabular}{|c|c|c|c|c|c|}
\hline \multicolumn{2}{|c|}{$\begin{array}{c}\text { Independent } \\
\text { Variable }\end{array}$} & \multirow{2}{*}{\multicolumn{2}{|c|}{$\begin{array}{c}\text { Dependent } \\
\text { Variable }\end{array}$}} & \multirow{2}{*}{$\begin{array}{c}\text { Standardized } \\
\text { Estimates }\end{array}$} & \multirow{2}{*}{$\begin{array}{r}t \text {-Values } \\
4.890^{* *}\end{array}$} \\
\hline $\mathrm{H} 1$ & FIT & & & & \\
\hline $\mathrm{H} 2$ & LIN & $\rightarrow$ & JS & -0.076 & -0.939 \\
\hline $\mathrm{H} 3$ & SAC & $\rightarrow$ & JS & 0.593 & $8.221^{* *}$ \\
\hline $\mathrm{H} 4$ & JS & $\rightarrow$ & SE & 0.225 & $3.644^{* *}$ \\
\hline H5 & JS & $\rightarrow$ & $\mathrm{TI}$ & -0.0679 & -10.561 ** \\
\hline H6 & JS & $\rightarrow$ & PJP & 0.131 & $2.415^{*}$ \\
\hline $\mathrm{H} 7$ & JS & $\rightarrow$ & WE & 0.323 & $5.680^{* *}$ \\
\hline $\mathrm{H} 8$ & SE & $\rightarrow$ & TI & 0.231 & $4.552 * *$ \\
\hline H9 & SE & $\rightarrow$ & PJP & 0.567 & 10.050 ** \\
\hline H10 & SE & $\rightarrow$ & WE & 0.537 & $9.240^{* *}$ \\
\hline \multicolumn{2}{|c|}{$\begin{array}{c}\text { Total impact on TI } \\
\beta \text { FIT }=-0.258^{* *} \\
\beta \text { LIN }=0.048 \\
\beta \text { SAC }=-0.372^{* *} \\
\text { Total impact on PJP } \\
\beta \text { FIT }=0.106^{* *} \\
\beta \text { LIN }=-0.020 \\
\beta \text { SAC }=0.153^{* *} \\
\beta \text { JS }=0.258^{* *} \\
\text { Total impact on WE } \\
\beta \text { FIT }=0.183^{* *} \\
\beta \text { LIN }=-0.034 \\
\beta \text { SAC }=0.263^{* *} \\
\beta \text { JS }=0.444^{* *}\end{array}$} & \multicolumn{2}{|c|}{$\begin{array}{c}\text { Total variance explained }\left(\mathrm{R}^{2}\right): \\
\mathrm{R}^{2} \text { for JS }=0.738 \\
\mathrm{R}^{2} \text { for } \mathrm{SE}=0.051 \\
\mathrm{R}^{2} \text { for } \mathrm{TI}=0.444 \\
\mathrm{R}^{2} \text { for PJP }=0.372 \\
\mathrm{R}^{2} \text { for } \mathrm{WE}=0.471 \\
\text { Goodness }- \text { of- } \text { fit statistics: } \\
\chi^{2}=777.032, d f=258, p<0.000 \\
\chi^{2} / d f=3.035, \mathrm{RMSEA}=0.080, \\
\text { CFI }=0.914, \mathrm{IFI}=0.914, \\
\text { TLI }=0.899\end{array}$} & 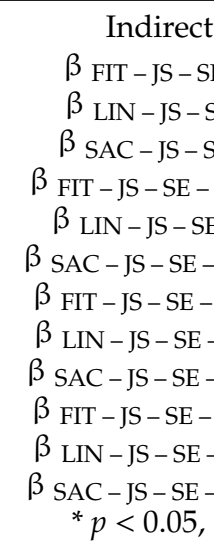 & $\begin{array}{l}\text { pact: } \\
0.093^{* *} \\
-0.017 \\
0.134^{* *} \\
=-0.258^{* *} \\
=0.048 \\
=-0.372^{* *} \\
=0.106^{* *} \\
=-0.020 \\
=0.153^{* *} \\
=0.183^{* *} \\
=-0.034 \\
=0.263^{* *} \\
<0.01\end{array}$ \\
\hline
\end{tabular}

Note. FIT $=$ fit, LIN $=$ links, SAC $=$ sacrifice, JS $=$ job satisfaction, SE $=$ self-efficacy, TI $=$ turnover intention, $\mathrm{PJP}=$ perceived job performance, $\mathrm{WE}=$ work engagement. ${ }^{*} p<0.05,{ }^{* *} p<0.01$.

Hypotheses 1-3 were tested. The results indicated that fit $(\mathrm{H} 1: \beta=0.412, p<0.01)$ and sacrifice (H3: $\beta=0.593, p<0.01)$ had a significant influence on job satisfaction, while Link (H2: $\beta=-0.076$, $p>0.05$ ) did not have a significant influence on job satisfaction. Therefore, hypotheses 1 and 3 were accepted, and hypothesis 2 was rejected. This result also rejected null hypotheses 1 and 3, but failed to reject null hypothesis 2 . Then, the relationships of job satisfaction with self-efficacy, turnover intention, perceived job performance and work engagement (Hypotheses 4-7) were tested. The results indicated that job satisfaction had significant influences on self-efficacy (H4: $\beta=0.225, p<0.01)$, turnover intention (H5: $\beta=-0.679, p<0.01$ ), perceived job performance (H6: $\beta=0.131, p<0.05$ ), and work engagement (H7: $\beta=0.323, p<0.01)$. Thus, hypotheses $4-7$ were all accepted. These results also succeed in rejecting null hypotheses 4-7. Lastly, the results of testing the relationships of self-efficacy on turnover intention, perceived job performance and work engagement (Hypotheses 8-10) are as follows. The influence of self-efficacy on various factors were found to be turnover intention (H8: $\beta=0.231$, $p<0.01$ ), perceived job performance (H9: $\beta=0.567, p<0.01)$, and work engagement $(\mathrm{H} 10: \beta=0.537$, $p<0.01)$, respectively. These results indicated the reverse of what Hypothesis 8 had presented earlier. In other words, the influence was found to be statistically meaningful; however, higher self-efficacy 
had led to higher turnover intention, instead of a lower turnover intention. Therefore, hypothesis 8 was rejected, and hypotheses 9 and 10 were accepted. These results also rejected null hypotheses 9 and 10 , but failed to reject null hypothesis 8 .

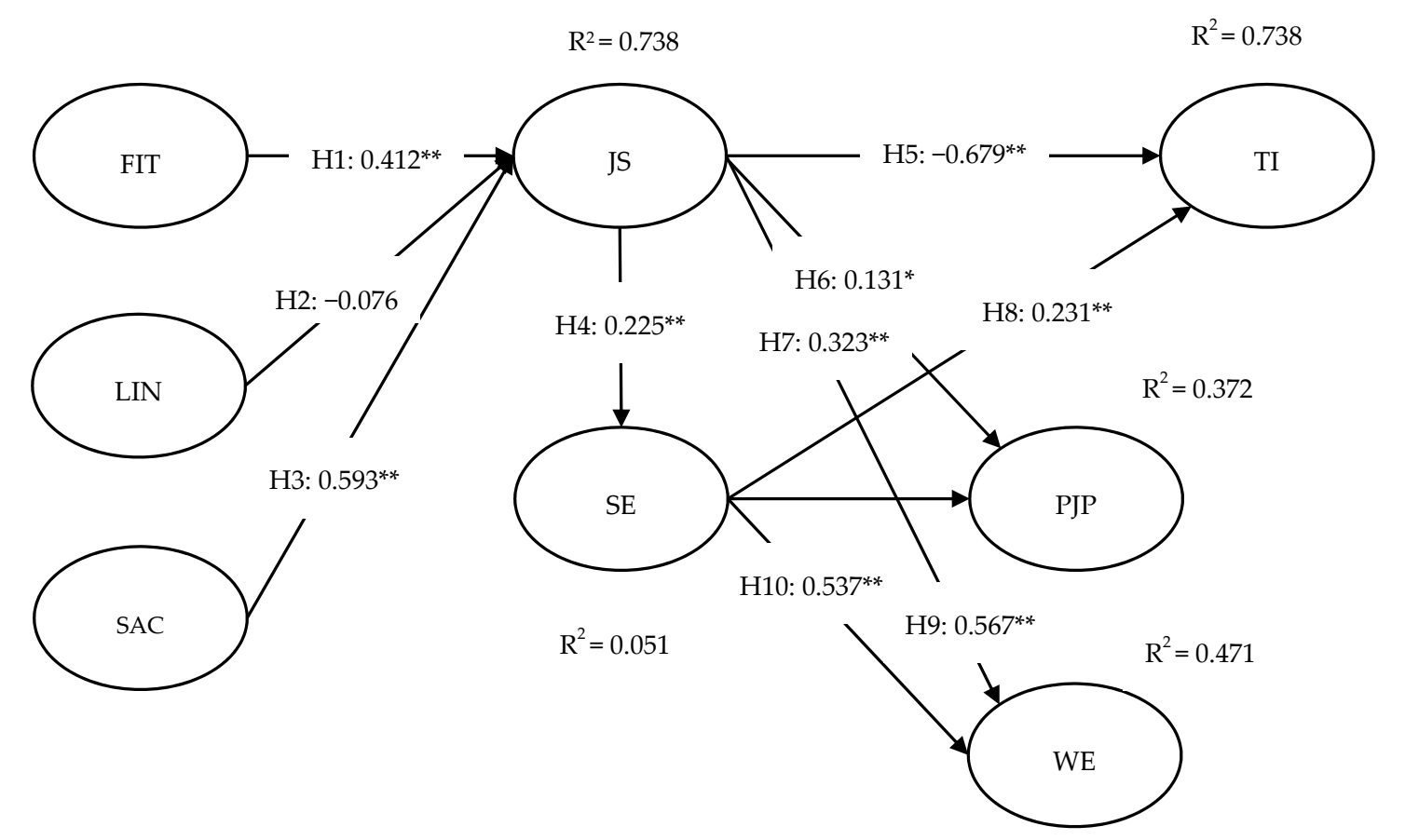

Note1. $\mathrm{FIT}=$ fit, $\mathrm{LIN}=$ links, $\mathrm{SAC}=$ sacrifice, $\mathrm{JS}=$ job satisfaction, $\mathrm{SE}=$ self-efficacy, $\mathrm{TI}=$ turnover intention, $\mathrm{PJP}=$ perceived job performance, $\mathrm{WE}=$ work engagement. Note2. Goodness-of-fit statistics: $\chi^{2}=777.032, d f=258, \mathrm{p}<$ $0.000, \chi^{2} / d f=3.035$, RMSEA $=0.080, \mathrm{CFI}=0.914, \mathrm{IFI}=0.914, \mathrm{TLI}=0.899 .{ }^{*} p<0.05,{ }^{* *} p<0.01$.

Figure 2. The structural equation modeling and hypotheses testing results.

Generally, it is known that using a mediating framework within a theoretical model can assist with understanding the complex relationships in study structures [59]. Verification of indirect effects of the sub factors of job embeddedness (i.e., fit, links, and sacrifice) on self-efficacy, turnover intention, perceived job performance, and job commitment was conducted. The results indicated that fit $\left(\beta_{\text {FIT }-\mathrm{JS}-\mathrm{SE}}=0.093, p<0.01 ; \beta\right.$ FIT $-\mathrm{JS}-\mathrm{SE}-\mathrm{TI}=-0.258, p<0.01 ; \beta$ FIT $-\mathrm{JS}-\mathrm{SE}-\mathrm{PJP}=0.106, p<0.01$; $\beta$ FIT - JS $-\mathrm{SE}-\mathrm{WE}=0.183, p<0.01)$ and sacrifice $(\beta \mathrm{SAC}-\mathrm{JS}-\mathrm{SE}=0.134, p<0.01 ; \beta \mathrm{SAC}-\mathrm{JS}-\mathrm{SE}-\mathrm{TI}=-0.372$, $p<0.01 ; \beta$ SAC - JS - SE - PJP $=0.153, p<0.01 ; \beta$ SAC - JS - SE - WE $=0.263, p<0.01)$ had significant indirect influences on turnover intention, perceived job performance and work engagement. These results indicate that job satisfaction and self-efficacy have shown important mediating effects within the proposed conceptual framework.

\section{Discussion and Implications}

The most important discovery of this study is that an employee's voluntary attitude towards voluntarily remaining rather than leaving the organization improves organizational performance measures such as employee satisfaction, attachment, and work engagement. In other words, job embeddedness, which comprises fit, links, and sacrifice, is a variable that improves active employee and is an important means to improve an organization's financial and non-financial performance. Numerous previous studies have investigated the damage to companies caused by voluntary or involuntary turnover due to external environmental factors. Unlike previous studies, however, this study drew the conclusion that a firm's performance can be further maximized when employees do not leave the company and stay voluntarily. These results are different and significant when compared to those from previous studies. Therefore, job embeddedness may provide meaningful implications in that it both creates and aids in understanding 
its positive effects on hotel organizations. Embeddedness also minimizes employee turnover, which causes great loss to the organization.

According to the data analyzed in this study, among the constituents of job embeddedness, fit and sacrifice were found to have a significant influence on all dependent variables presented in the study. However, the link variable did not have significant influence on the dependent variable. The results of verifying total effect sizes are as follows. First, the largest total effect size on turnover intention was from sacrifice. Second, the largest total effect sizes on perceived work performance and work engagement were from job satisfaction. In other words, variables that directly link the employees themselves with the organization such as fit, sacrifice and job satisfaction had the most significant influences. These results are notable, especially given that $87 \%$ of the study participants are in their $20 \mathrm{~s}$ and 30s. Employees in their 20s and 30s, referred to as the new generation, have grown and matured in environments characterized by higher economic prosperity owing to rapid economic growth, internationalization and development of information technologies. Thus, they tend to value themselves over putting the organization at the forefront. In other words, individuals in the new generation have stronger individualistic tendencies. As such, the will to stay within an organization and the will to engage in proactive work can be maximized when the employee considers themselves and the organization to be a great fit, and when they expect large sacrifices to be made when they leave the organization.

Hypothesis 8 shed light on such individualistic attitudes of the new-generation employees. The hypothesis presented in this study stated that self-efficacy had a negative influence on turnover intention. However, the proposed hypothesis was rejected, and it was found that self-efficacy had a positive influence on turnover intention. In other words, with higher confidence in their own abilities, employees can leave the organization in search of better conditions (i.e., salary, work environment, welfare, employee-centric attitudes of the organization and social reputation). This is in contrast to existing studies that have asserted that the will to remain within an organization is due to the relationships with colleagues, and affinity towards related networks and their activities. In other words, individuals in the new generation can be seen has having higher interest in their physical benefits when compared to members of the old generation. These results indicate that the members of the new generation desire self-development and better work environments, and engage in voluntary efforts to develop their own skills to seek out better workplaces. Ultimately, it can be concluded that the concept of work-for-life workplaces perceived by the older generation is now defunct.

Turnover intention, defined as employees wanting better conditions and engaging in seeking out such conditions, leads to negative influences on the organization (i.e., expenses incurred in the hiring process of new employees, training, psychological confusion of other employees and lower affinity towards the organization). Hence, organizations require efforts to reduce turnover intention of employees. As such, the results of this study can provide practical considerations in reducing the turnover phenomenon that is common in hotel enterprises. First, an acceptable level of materialistic rewards (i.e., incentives, special vacations) should be offered. This is backed by the fact that sacrifice has the largest total effect size on turnover intention among the constituents of job embeddedness. Thus, providing adequate rewards is the most effective method in increasing proactive attitude towards work and reduces turnover intention. Second, the work and personal lives of individuals must be clearly separated to guarantee sufficient individual privacy and leisure time for employees. Employees are constantly exposed to work-related emails, SMS, and text messages via smart devices outside of working hours. Therefore, they are directly or indirectly linked to work even outside of working hours. This indicates that employees are connected either directly or indirectly to work even outside of work hours. Therefore, it is necessary to refrain from contacting the employees with work-related issues outside of regular work hours to protect the privacy of individuals. Third, organizations must make efforts to create a culture that can boost employees' loyalty to the company. For example, if the organization provides fair administrative processes (i.e., promotions, bonuses, processes and correlations), employees could learn to appreciate the company and stay true to their roles. 
The concept of voluntary turnover, in tune with the changing times, is morphing though methods of employee self-development. Turnover can result in losses for the organization and lead to psychological burdens where employees must adapt themselves to new environments. Thus, it may have negative impacts on both the organization and the employee. As such, firms must lead the employees to strive to be satisfied and choose to remain within the current organization. Given this, it can be concluded that this study has presented meaningful results where both the firm and the employee can both be satisfied.

\section{Limitations and Future Research}

The results of this study provided important clues that determine active work attitude and turnover intention of hotel employees; however, the study has a few limitations. First, most respondents (87\%) are from the generation of those in their 20s and 30s. The concept of turnover may be perceived differently across generations even if they work in the same organization. Therefore, further research must examine the generational differences in job embeddedness and turnover intention perceived by the new generation and the older generation. Second, the data of this study were obtained from employees with South Korean citizenship working in a luxury hotel located in South Korea. Thus, the results cannot be generalized to employees in other countries or continents. Accordingly, it is necessary to promote generalization by expanding the scope of sampling. Third, all those who participated in this survey were employees of 5-star hotels located in Seoul and the capital region. This highlights the need to classify the hotels into various types (luxury, upscale, midscale, economy) for further research.

Author Contributions: Conceptualization, H.H. and A.A.-M.; methodology, J.Y.; writing-original draft preparation, J.Y.; writing-review and editing, A.L.; visualization, J.Y. and A.L.; supervision, A.A.-M. and G.G.; project administration, H.H. and A.A.-M.; funding acquisition, A.A.-M. and G.G. All authors have read and agreed to the published version of the manuscript.

Funding: This research received no external funding.

Conflicts of Interest: The authors declare no conflict of interest.

\section{Appendix A}

Table A1. Job embeddedness.

\begin{tabular}{ll}
\hline & \multicolumn{1}{c}{ Fit } \\
- & My job utilizes my skills and talents well. \\
- $\quad$ I fell I am a good match for this organization. \\
- $\quad$ I fit with this organization's working style. \\
\hline
\end{tabular}


Table A1. Cont.

\begin{tabular}{l} 
Self-efficacy \\
- $\quad$ I have all the skills needed to perform my job very well. \\
- $\quad$ I have confidence in my ability to do my job. \\
\hline
\end{tabular}

\section{References}

1. Yu, J.; Lee, A.; Han, H. Relationships among organizational justice, job embeddedness, self-efficacy, organization citizenship behavior and turnover intention in a hotel organization. Korean J. Hosp. Tour. 2017, 26, 89-106. [CrossRef]

2. Samsung Economic Research Institute. BRAVO Generation. 2009. Available online: http://www.seri.org/db/ dbReptV.html?g_menu=02\&s_menu=0202\&pubkey=db20091021001 (accessed on 22 April 2020).

3. Ballout, H.I. Work-family conflict and career success: The effects of domain specific determinants. J. Manag. Dev. 2008, 27, 437-466. [CrossRef]

4. Lee, J.H.; Shin, K.H.; Baeck, S.G.; Heo, C.G. The effectiveness of job embeddedness in turnover studies: A meta-analysis. Korean J. Ind. Org. Psychol. 2014, 27, 743-779. [CrossRef]

5. Lee, T.W.; Mitchell, T.R. An alternative approach: The unfolding model of voluntary employee turnover. Acad. Manag. Rev. 1994, 19, 51-89. [CrossRef]

6. Griffeth, R.W.; Hom, P.W.; Gaertner, S. A meta-analysis of antecedents and correlates of employee turnover: Update, moderator tests, and research implications for the next millennium. J. Manag. 2000, 26, 463-488. [CrossRef]

7. Mallol, C.M.; Holtom, B.C.; Lee, T.W. Job embeddedness in a culturally diverse environment. J. Bus. Psychol. 2007, 22, 35-44. [CrossRef]

8. Holtom, B.C.; Inderrieden, E.J. Integrating the unfolding model and job embeddedness model to better understand voluntary turnover. J. Manag. Issues 2006, 18, 435-452.

9. Holtom, B.C.; Mitchell, T.R.; Lee, T.W. Increasing human and social capital by applying job embeddedness theory. Organ. Dyn. 2006, 35, 316-331. [CrossRef]

10. Holtom, B.C.; O'Neill, B.S. Job embeddedness: A theoretical foundation for developing a comprehensive nurse retention plan. J. Nurs. Adm. 2004, 34, 216-227. [CrossRef]

11. Lee, T.W.; Mitchell, T.R.; Sablynski, C.J.; Burton, J.P.; Holtom, B.C. The effects of job embeddedness on organizational citizenship, job performance, volitional absences, and voluntary turnover. Acad. Manag. J. 2004, 47, 711-722.

12. Mitchell, T.R.; Holtom, B.C.; Lee, T.W.; Sablynski, C.J.; Erez, M. Why people stay, using job embeddedness to predict voluntary turnover. Acad. Manag. J. 2001, 44, 1102-1121.

13. THE KUKMIN DAILY. Preparing to Leave. 2011. Available online: http://news.kmib.co.kr/article/view.asp? arcid $=0005450644$ (accessed on 29 April 2020). 
14. YONHAP NEWS AGENCY. More than 30\% of College Graduates Left the Company within Three Years. 2016. Available online: http://www.yonhapnews.co.kr/bulletin/2016/10/26/0200000000AKR20161026041100009. HTML?input=1195m (accessed on 3 May 2020).

15. Ramli, A.A.; Salahudin, S.N.; Zainol, Z.; Suandi, T. Turnover intention among academics: A case study of private higher learning education in Klang Valley. J. Soc. Sci. Humanit. 2014, 22, 321-334.

16. Allen, D.G. Do organizational socialization tactics influence newcomer embeddedness and turnover? J. Manag. 2006, 32, 237-256. [CrossRef]

17. Locke, E.A. The Nature and Causes of Job Satisfaction. Handb. Ind. Org. Psychol. 1976, 1, 1297-1343.

18. Koo, B.; Yu, J.; Chua, B.L.; Lee, S.; Han, H. Relationships among emotional and material rewards, job satisfaction, burnout, affective commitment, job performance, and turnover intention in the hotel industry. J. Qual. Assur. Hosp. Tour. 2020, 21, 371-401. [CrossRef]

19. Charles, K.R.; Marshall, L.H. Motivational preference of Caribbean hotel workers: An exploratory study. Int. J. Contemp. Hosp. Manag. 1991, 4, 25-29. [CrossRef]

20. Davis, G. Job satisfaction survey among employees in small business. J. Small Bus. Enterp. Dev. 2004, 11, 495-503. [CrossRef]

21. Netemeyer, R.G.; Maxham, J.G. Employee versus supervisor ratings of performance in the retail customer service sector: Differences in predictive validity for customer outcomes. J. Retail. 2007, 83, 131-145. [CrossRef]

22. Karatepe, O.M.; Uludag, O. Conflict, exhaustion, and motivation: A study of frontline employees in northern Cyprus hotels. Hosp. Manag. 2007, 26, 645-665. [CrossRef]

23. Messersmith, J.G.; Patel, P.C.; Lepak, D.P.; Gould-Williams, J.S. Unlocking the black box: Exploring the link between high-performance work systems and performance. J. Appl. Psychol. 2011, 96, 1105-1118. [CrossRef]

24. Hartline, M.D.; Ferrell, O.C. The management of customer-contact service employees: An empirical investigation. J. Mark. 1996, 60, 52-70. [CrossRef]

25. Kim, S.S.; Im, J.; Hwang, J. The effects of mentoring on role stress, job attitude, and turnover intention in the hotel industry. Int. J. Hosp. Manag. 2015, 48, 68-82. [CrossRef]

26. Bandura, A. Self-efficacy: Toward a unifying theory of behavior change. Psychol. Rev. 1977, 82, 191-195. [CrossRef]

27. Wood, R.; Mento, E.; Locke, A. Task complexity as a moderator of goal effect: A meta-analysis. J. Appl. Psychol. 1987, 72, 416-425. [CrossRef]

28. Bandura, A.; Schunk, D. Cultivating competence, self-efficacy, and intrinsic interest through proximal self-motivation. J. Personal. Soc. Psychol. 1981, 41, 586-598. [CrossRef]

29. Bandura, A. Self-efficacy mechanism in human agency. Am. Psychol. 1982, 37, 122-147. [CrossRef]

30. Riggs, M.L.; Warka, J.; Babasa, B. Development and validation of self-efficacy and outcome expectancy scales for job-related applications. Educ. Psychol. Meas. 1994, 54, 793-802. [CrossRef]

31. Walumbwa, F.O.; Hartnell, C.A.; Oke, A. Servant leadership, procedural justice climate, service climate, employee attitudes, and organizational citizenship behavior: A cross-level investigation. J. Appl. Psychol. 2010, 95, 517-529. [CrossRef]

32. Stajkovic, A.D.; Luthans, F. Self-efficacy and work-related performance, a meta-analysis. Psychol. Bull. 1998, 124, 240-262. [CrossRef]

33. Bandura, A.; Adams, N.E.; Hardy, A.B.; Howells, G.N. Tests of the generality of self-efficacy theory. Cogn. Ther. Res. 1980, 4, 39-66. [CrossRef]

34. King, A.S. Self-fulfilling prophecies in training the hard-core: Supervisors' expectation and the underprivileged workers' performance. Soc. Sci. Q. 1971, 52, 369-378.

35. Harris, M.J.; Rosenthal, R. Mediation of interpersonal expectancy effects, 31 meta- analysis. Psychol. Bull. 1985, 97, 363-386. [CrossRef]

36. Gist, M.E. The influence of training method on self-efficacy and idea generation among managers. Acad. Manag. Rev. 1989, 42, 787-805. [CrossRef]

37. Wood, R.; Bandura, A.; Bailey, T. Mechanisms governing organizational performance in complex decision-making environments. Organ. Behav. Hum. Decis. Process. 1990, 46, 181-201. [CrossRef]

38. Chen, G.; Webber, S.S.; Bliese, P.D.; Mathieu, J.E.; Payne, S.C.; Born, D.H.; Zaccaro, S.J. Simultaneous examination of the antecedents and consequence of efficacy beliefs at multiple levels of analysis. Hum. Perform. 2002, 15, 381-409. [CrossRef] 
39. Mobley, W.H. Employee Turnover in Causes Consequences E Control; Addison-Wesley Publishing Company: London, UK, 1982.

40. Griffeth, R.W.; Hom, P.W. Retaining Valued Employees; Sage: Thousand Oaks, CA, USA, 2001.

41. Tett, R.P.; Meyer, J.P. Job Satisfaction, organizational commitment, turnover intention, and turnover: Path analyses based on Meta-Analytic Findings. Pers. Psychol. 1993, 46, 259-293. [CrossRef]

42. Steel, R.P.; Ovalle, N.K. A review and meta-analysis of research on the relationship between behavioral intentions and employee turnover. J. Appl. Psychol. 1984, 69, 673-686. [CrossRef]

43. Karatepe, O.M.; Shahriari, S. Job Embeddedness as a moderator of the impact of organisational justice on turnover intentions: A study in Iran. Int. J. Tour. Res. 2014, 16, 22-32. [CrossRef]

44. Milkovich, G.T.; Boudreau, J.W. Human Resource Management; Irwin Inc.: Boston, MA, USA, 1994.

45. Salmivalli, C. Feeling good about oneself, being bad to others? Remarks on self-esteem, hospitality, and aggressive behavior. Aggress. Violent Behav. 2001, 6, 375-393. [CrossRef]

46. Schaufeli, W.B.; Salanova, M.; Gonzalez-Rom, V.; Bakker, A.B. The measurement of engagement and burnout: A confirmative analytic approach. J. Happiness Stud. 2002, 3, 71-92. [CrossRef]

47. Chaudhary, R.; Rangnekar, S.; Barua, M. Relation between human resource development climate and employee engagement: Results from India. Eur. J. Psychol. 2011, 7, 664-685. [CrossRef]

48. Ramesh, A.; Gelfand, M.J. Will they stay or will they go? The role of job embeddedness in predicting turnover in individualistic and collectivistic cultures. J. Appl. Psychol. 2010, 95, 807-823. [CrossRef] [PubMed]

49. Jiang, K.; Liu, D.; McKay, P.F.; Lee, T.W.; Mitchell, T.R. When and how is job embeddedness predictive of turnover? A meta-analytic investigation. J. Appl. Psychol. 2012, 97, 1077-1096. [CrossRef] [PubMed]

50. Judge, T.A.; Bono, J.E. Relationship of core self-evaluations traits-self-esteem, generalized self-efficacy, locus of control, and emotional stability-with job satisfaction and job performance: A Meta-Analysis. J. Appl. Psychol. 2001, 86, 80-92. [CrossRef] [PubMed]

51. Jang, J.; George, R.T. Understanding the influence of polychronicity on job satisfaction and turnover intention: A study of non-supervisory hotel employees. Int. J. Hosp. Manag. 2012, 31, 588-595. [CrossRef]

52. Moshin, M.; Safdar, M.; Asghar, F.; Jamal, F. Assessment of drinking water quality and its impact on residents health in bahawalpur city. Int. J. Humanit. Soc. Sci. 2013, 3, 114-128.

53. Arnett, D.B.; Laverie, D.A.; McLane, C. Using job satisfaction and pride as internal-marketing tools. Cornell Hosp. Q. 2002, 43, 87-96. [CrossRef]

54. Chen, H.T.; Wang, C.H. Incivility, satisfaction and turnover intention of tourist hotel chefs: Moderating effects of emotional intelligence. Int. J. Contemp. Hosp. Manag. 2019, 31, 2034-2053. [CrossRef]

55. Lu, A.C.C.; Gursoy, D. Impact of job burnout on satisfaction and turnover intention: Do generational differences matter? J. Hosp. Tour. Res. 2016, 40, 210-235. [CrossRef]

56. Steers, R.M. Antecedents and outcomes of organizational commitment. Adm. Sci. Q. 1977, 22, 45-56. [CrossRef]

57. Mathieu, J.E.; Zajac, D.M. A review and meta-analysis of the antecedents, correlates, and consequences of organizational commitment. Psychol. Bull. 1990, 108, 171-194. [CrossRef]

58. Karatepe, O.M.; Arasli, H.; Khan, A. The impact of self-efficacy on job outcomes of hotel employees: Evidence from Northern Cyprus. Int. J. Hosp. Tour. Adm. 2007, 8, 23-46.

59. Han, H.; Ryu, K. The theory of repurchase decision-making (TRD): Identifying the critical factors in the post-purchase decision-making process. Int. J. Hosp. Manag. 2012, 31, 786-797. [CrossRef]

60. Anderson, J.C.; Gerbing, D.W. Structural equation modeling in practice: A review and recommended two-step approach. Psychol. Bull. 1988, 103, 411-423. [CrossRef]

61. Fornell, C.; Larcker, D.F. Evaluating structural equation models with unobservable variables and measurement error. J. Mark. Res. 1981, 18, 39-50. [CrossRef]

(C) 2020 by the authors. Licensee MDPI, Basel, Switzerland. This article is an open access article distributed under the terms and conditions of the Creative Commons Attribution (CC BY) license (http://creativecommons.org/licenses/by/4.0/). 